\title{
The Effect of Graphic Organizer upon Reading Comprehension of the Twelfth Grade Students of SMAN 1 Sukawati in Academic Year 2015/2016
}

\author{
A.A. M.I Dewi, A.A.I.N Marhaeni, Nkm. A.Suwastini \\ Jurusan Pendidikan Bahasa Inggris \\ Universitas Pendidikan Ganesha \\ Singaraja, Indonesia \\ e-mail: agungmithaindra@gmail.com, \\ ngr.marhaeni@undiksha.ac.id,ariesuwastini80@gmail.com
}

\begin{abstract}
Abstrak
Penelitian ini bertujuan untuk menyelidiki apakah terdapat pengaruh yang signifikan terhadap pemahaman membaca siswa kelas XII yang diajar menggunakan Graphic Organizer dengan siswa yang diajar menggunakan teknik konvensional. Penelitian ini dalam bentuk penelitian eksperimen semu (Quasi Experimenta). Posttest Only Control Group digunakan sebagai desain penelitian ini. Penelitian ini dilaksanakan di SMA N 1 Sukawati. Populasi penelitian ini adalah siswa kelas XII tahun ajaran 2015/2016. Sampel penelitian ini adalah 75 siswa yang telah dipilih dengan menggunakan teknik sampel random atau acak; terdiri dari 37 siswa kelas XII IPA 2 sebagai kelompok eksperimen dan 38 siswa kelas XII IPA 3 sebagai kelompok kontrol. Hasil analisis data menunjukkan bahwa terdapat pengaruh yang signifikan terhadap pemahaman membaca siswa kelas XII yang diajar menggunakan Graphic

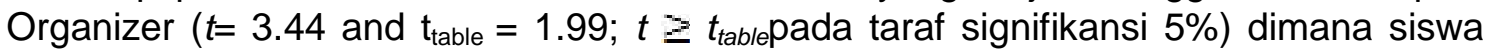
yang diajar menggunakan Graphic Organizer menunjukkan pemahaman membaca yang lebih baik dibandingkan dengan siswa yang diajar menggunakan teknik konvensional. Berdasarkan hasil tersebut, dapat disimpulkan bahwa Graphic Organizer memberikan pengaruh yang signifikan terhadap pemahaman membaca siswa kelas XII di SMA N 1 Sukawati tahun ajaran 2015/2016.
\end{abstract}

Kata kunci: EFL, Graphic Organizer, Pemahaman Membaca

\begin{abstract}
This research was aimed to investigate whether there was a significant effect on reading comprehension of the twelfth grade students who were taught by using Graphic Organizer and who were taught by using conventional technique. This research was Quasi-Experimental research. Post-Test Only Control Group was used as the design of this research. This research was conducted at SMA N 1 Sukawati. The population of this research was the twelfth grade students in academic year $2015 / 2016$. The sample was 75 students that were selected through random sampling; 37 students of XII IPA as experimental group and 38 students of XII IPA 3 as control group. The result of data analysis showed that there was a significant effect on reading comprehension of the twelfth grade students who were taught by using Graphic Organizer ( $t=3.44$ and $t_{\text {table }}=1.99 ; t \geq t_{\text {table }}$ on the level of significance $\left.5 \%\right)$ in which the students who were taught by using Graphic Organizer performed better reading comprehension than who were taught by using conventional technique.
\end{abstract}


Based on this result, it could be inferred that Graphic Organizer gave significant effect on the twelfth grade students' reading comprehension compared at SMA N 1 Sukawati academic year 2015/2016.

Key words: EFL, Graphic Organizer, Reading Comprehension.

\section{INTRODUCTION}

English has been agreed as international language by many countries. Due to its role as international language, English is not only learnt by the countries that use English as native language, but also by the countries that use English as second language (L2) or foreign language (EFL). As the result, those countries include English into their national curriculum. Indonesia is one of the EFL countries that include English into its national curriculum.

English teaching in Indonesia has been based on the curriculum designed by the central government throughout provision of curriculum policies. In 2006, the government published a curriculum called School Based Curriculum (Kurikulum Tingkat Satuan Pendidikan, KTSP) as the development of the previous curriculum;Competence Based Curriculum (Kurikulum Berbasis Kompetensi, KBK) in 2004. According to Badan Standar Nasional Pendidikan (2006, p. 5), School Based Curriculum (KTSP) is an operational curriculum designed and implemented by the school. Even though the school is given authority to design the curriculum, the criteria is still given by the government in order to keep the quality of curriculum itself. The development of School Based Curriculum refers to national education standard to achieve national education objectives. National education standard consists of eight standards. Two of those eight standards, content standard (Standar Isi, SI) and output standard (Standar Kompetensi Lulusan, SKL), are the primary guidelines for the school to develop the curriculum.
One of primary guidelines that has to be followed by the school in developing the curriculum is content standard (SI). BSNP (2006) states that content standard consists of basic framework and curriculum structure, standard competency (Standar Kompetensi, SK) and basic competency (Kompetensi Dasar, KD). In School Based Curriculum, the students are regarded as succeed in learning if they can fulfill the minimum criteria which consists of standard competency (SK) and basic competency (KD). Related to English subject, those competencies can be attained by mastering four English language skills, namely: listening, speaking, reading and writing. Moreover, the students have to master other language aspects like grammar points, vocabulary pronunciation, etc which are commonly taught explicitly in those four language skills.

One of the essential language skills is reading.According to Wiriyani (2011, p. 2), in relation to academic affair, reading positively affects many aspect of students' academic performance, for example in examinations. The students face some kinds of examination to assess their language mastery. In the final examination and national examination, the students are mostly tested their ability in comprehending texts. Consequently, it is very important for them to emphasize on their reading competency.

As what has been explained previously that reading is one of essential skills in English language learning, there are some components that have to be achieved by the students. Pusat Kurikulum Badan Penelitian dan Pengembangan 
Departemen Pendidikan Nasional (2003, as cited in Wiriyani, 2011, p. 2) categorizes four components in reading, namely: first is the ability to obtain general and specific information from written text, second is the ability to recognize the main idea and specific ideas in the text explicitly and implicitly, third is the ability to guess word meaning, phrase or sentences based on the context, and fourth is the ability to guess the meaning of reference. Those four components are used as the indicators to determine whether the students are successful in reading or not.

Johnson (2008, p. 3) states that reading is the practice of using text to create meaning. When dealing with written text, a reader has to be able to create meaning on the words and how the ideas connected.Because, if there is no meaning being created, there is no reading taking place. Thus, it is important to consider to the elements of reading in order to get meaningful reading. National Institute of Child Health and Human Development (NICHD, 2000 in Learning Point Associates, 2004, p. 1) states five essential elements of reading, namely: phonemic awareness, phonics, fluency, vocabulary and comprehension.

Reading comprehension is one of five essential elements of reading. However, problem arises when the students read a text. Based on previous research conducted by Sam \& Rajan (2013, p. 155), when reading students may be good at recognizing the meaning of every word and pronouncing it, but they may have difficulty in understanding the main idea of the text. This causes fragmentary understanding. If they have fragmentary understanding, they will fail in following schemata while reading. Consequently, they will fail in identifying the main idea and how it is developed in the body of a text or a passage. This problem will impact their ability in answering the comprehension questions. That is why it is important to provide effective reading strategy to help students comprehending the text better.

Mahmood et al. (2013, p. 229) argue that effective English reading strategies help building English reading metacognition and increasing English reading comprehension. One of the purposes of reading is to obtain reading comprehension for long term-memory which can shape individual's schemata or experiences. To meet this purpose, reading strategies which cover cognitive and metacognitive process can be applied. Among so many choices of cognitive reading strategies, Graphic Organizer is applied in this research. Graphic Organizer strategy is not too familiar yet to be implemented for English language teaching (ELT) strategy in Indonesia. That is why the researcher wants to investigate whether Graphic Organizer plays significant effect on Indonesian EFL students' reading comprehension or not. Besides, another reason to choose this strategy is Graphic Organizer provides learning through visual way. Graphic Organizer also gives alternative strategy to inefficient reading strategy in which students commonly read a text by translating its meaning into their first language in order to comprehend the text which is actually time consuming (Sam \& Rajan, 2013,p. 156).

The researches on the application of Graphic Organizer in ESL or EFL classes have been conducted by the researchers in many countries that learn English as second language or foreign language. One of the researches about Graphic Organizer has been conducted by Sam \& Rajan (2013) in eight grade students at a school in western part of Tamil Nadu, India. At this school, English was being taught as second language. The result of this research showed that there was significant different in reading comprehension of the students who were taught by Graphic Organizer and of those who were not. In this research, Graphic Organizer did not only give impact on the improvement of students' 
reading score, but also develop their creativity. By implementing Graphic Organizer, the students could create their own graphic.

The researcher had conducted the primary observation by interviewing one of the English teachers at SMA N 1 Sukawati. The results of the primary observation were: first, the students in twelfth grade had low motivation in learning English. Second, when given a written text, they showed no interest in reading the text; they were just reading aloud every single word without understanding what the text was about. Third, reading section took a lot time allotment because the teacher had the students to find out every word that they did not know the meaning on the dictionary. The conventional technique used by the teacher might create those problems. There were some alternative and effective strategies that could be used to overcome the problems, such as skimming, scanning, outlining, Graphic Organizer, three phase technique, etc. Among those effective reading strategies, the researcher had implemented Graphic Organizer in order to know whether it gave significant effect on the twelfth grade students' reading comprehension at SMA N 1 Sukawati.

Based on the explanation above about Graphic Organizer which theoretically could help students in comprehending text better, the researcher was interested in investigating whether or not the implementation of Graphic Organizer strategy contributed significant effect on reading comprehension of the twelfth grade students of SMA N 1 Sukawati in academic year 2105/2016.

The statement of the research problem could be stated 'Is there any significant effect on the reading comprehension of the twelfth grade students of SMA N 1 Sukawati who are taught by using Graphic Organizer strategy and who are taught by using conventional technique?'
In accordance with the research problem, the research was aimed to investigate whether there is a significant effect on the reading comprehension of the twelfth grade students who are taught by using Graphic Organizer strategy and who are taught by using conventional technique at SMA N 1 Sukawati in academic year 2015/2016.

Reading is one of the four major skills in learning English. Generally, reading is closely related to written text. When reading, the readers deal with many things; not only words, but also the meaning and the relation of the ideas. This statement is in line with the definition of reading stated by Johnson (2008, p. 3) in which he argues that reading as the practice of using text to create meaning. It means that if there is no meaning being created, there is no reading taking placeJohnson (2008, p. 3 ). Reading is not merely about how to pronounce words and how to find out the meaning on every word, but it is also about how to create meaning from the relation of word to word and how to relate the meaning of idea to idea of the text to get better comprehension of the whole text. Another definition is stated by Reyes (2011) in which he defines reading as a process of interaction among thought, language and personal experiences. While reading, the reader does not only decode the information from the text, but s/he also has to comprehend what the information is conveyed by the text. Using her/his thought, knowledge about the language and prior knowledge, the reader gathers the information from the text more easily. According to the definitions above, it can be concluded that reading is an activity of understanding information from a written text. Reading does not merely involve the ability in understanding word to word in the text, but also understanding the relation between the ideas, what information wants to conveyed by the writer and how to gain new information through 
the prior knowledge that already have been had by the readers.

Deyuan \& Yufen (2006, p. 214) state there are three stages of reading activity. The stages are continuous activity in which one stage followed by others. Those three stages are prereading activity, while reading activity, and post reading activity. In prereading activity, the teacher helps the students building their prior knowledge through introducing related vocabularies, encourage skimming, scanning and so on. In while-reading activity, the teacher provides some guidelines, in form of statement guidelines and pattern research guidlines, to help the students comprehending the text better. The third stage, the student integrate their prior knowledge or personal experience to new acquire information. The activities that can be provided by the teacher are reviewing and concluding.

Comprehending a written text is much better than just reading the written text in a glance without comprehend what writer wants to be conveyed, what information there are in the text, and how to gain the new information through the background knowledge that the readers already possess.Vaughn and Thompson (2004 in Salmi, 2011, p. 698) define Reading comprehension as dynamic construction of meaning. The meaning that the reader gets is the result of the combination of the text's input, reader's prior knowledge, manipulation of lexis, making inferences and relating thought. That is why reading is called an interactive process since it involves the interaction of the combined factors influence it. Snow (2002, p. 11) argues that reading is a process of simultaneously extracting and constructing meaning through interaction and involvement with written language. The words "extracting and constructing" are used because in reading, it is not only the text that can be a determinant of a reading comprehension, but also readers and activity. Comprehension is not simply occurred by extracting meaning from the text. While reading, the reader will construct different representations of the text which are also important for comprehension.Based on the theories of reading comprehension above, it can be concluded that reading comprehension is a process of understanding the information of the text which involves the interaction between the text and the readers.

According to Nor \& Jin (2012, p. 36)there are four factors influencing reading comprehension, namely: reader's knowledge of reading strategy, reader's background knowledge and attitude, teacher's reading approach and classroom environment and facilities. When a reader has an effective reading strategy, he can comprehend the text naturally so he can achieve reading comprehension. Effective reading strategies much more influence reader's reading comprehension skill. The second factor is background knowledge and attitude. The reader's background knowledge or non-visual information helps him to make meaning from the text and to try to find what information that wants to be conveyed by the writer because it is a brain, not the eyes that make meaning from the text. As a teacher, it is a must to find effective approaches and strategies to support teaching and learning process. In reading, teacher can use many effective strategies to help students to build up their prior knowledge before reading and build their interest in order to develop their reading comprehension. The last factor determined effective reading comprehension is classroom environment and facilities. Positive classroom environment can be created by having conducive classroom and providing supported facilities which can make the students more actively engage in learning process and they will more motivated in doing challenging tasks. 
Graphic Organize is based on Ausubel's assimilation theory of cognitive learning. Zaini et al. (2010, p. 17) states that Graphic Organizer is simply a graphical or spatial representation of text concepts. It is a learning strategy which involves translating words from linear form into visual structure.Kohler (2009) defines Graphic Organizer as a visual representation of knowledge. Graphic Organizers structure information into a pattern and use labels to help make relationships among discrete pieces of information clear.

The advantages of Graphic Organzier are stated by McKnight (2010, p. 1) in which Graphic Organizer helps the learners organize content and ideas and facilitate learners' comprehension of newly acquired information. Stull \& Mayer (2007, p. 808 ) also state the similar ideas of the advantages of using Graphic Organized as the previous ones in which by providing Graphic Organizer as a teaching strategy can induce students to engage in active learning, because they must think about how a linear text can be converted into a spatial structure such as a hierarchy or a flowchart. Nor \& Jin (2012, p. 33) state that Graphic Organizer provides an effective reading strategy that increase students' motivation, cooperative skill and reading skill. In completing or constructing the graphic, the students do not only work individually, but also they can work in pairs or in groups.

These are some designs of Graphic Organizer commonly used (Grabe and Stoller (2001) as cited in Ozturk (2012):

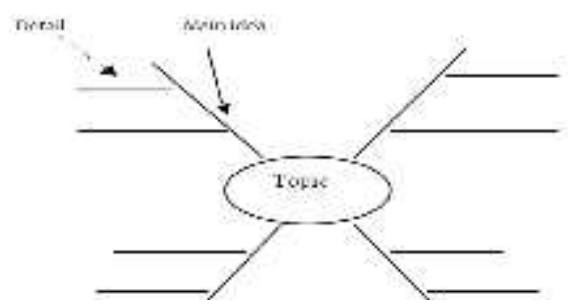

Figure 1 Spider Maps are for the text that describe topic

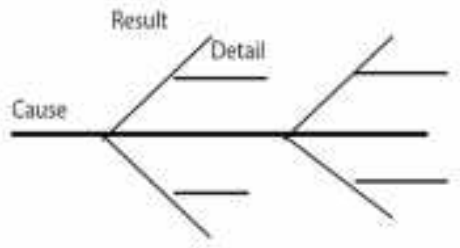

Figure 2 Fishbone are mostly used to show cause and effect relationship

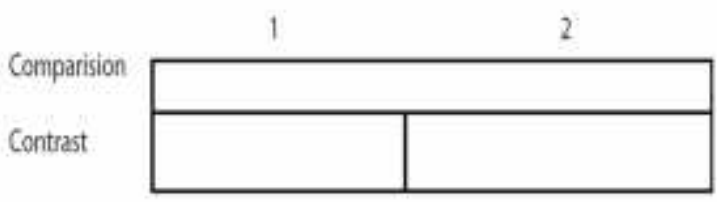

Figure 3 Comparison and Contrast type of GO shows the similarity and differences

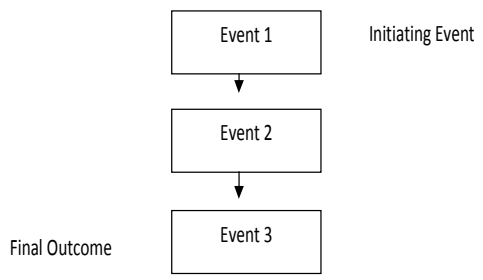

Figure 4 Series of Event Chains describes the stages or steps in a nrnness

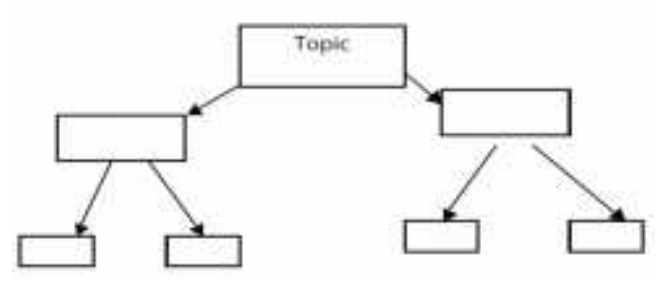

Figure 5 Network tress may show a hierachy, brancing procedure, classification, and cause of fact

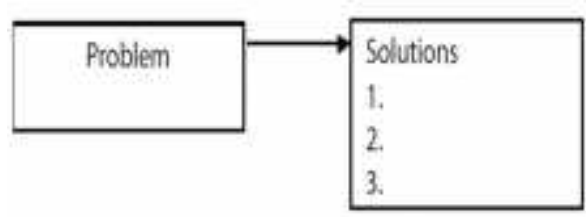

Figure 6 Problem and Solution GO is used to represent problem and solution in order to solve that nroblem. 
Each of them is suitable to be applied based on the type of information which needed from a text. In this research, the researchers used narrative and explanation genre of text for the reading texts. Both narrative and explanation text presented step by step of events, how one step leads to the next step and eventually to the final outcome. For that reason, series of event chains was applied in this research.

There are several instruction steps in implementing Graphic Organizer according to Walker (Walker,B.J, 1922; as cited in Wiriyani, 2011, p. 29): first, the teacher chooses a text related to the topic of curriculum. The second step is the teacher selects key words and concept in the text. Next, the teacher arranges the key words into a diagram picture of charts that show how the key word interrelated. In this step, the teacher only does the chart partially and the rest will be completed by the students within the teacher's guide. Fourth, the teacher adds a few familiar words to the diagram so that students can connect their prior knowledge with the new information. Fifth, the teacher presents the graphic organizer on the board and explains the relationship that comes across in the chart. In this step, the teacher gives the chance for the students to show their idea related to the chart given. Then, students are encouraged to explain how they think the information is related. The seventh step is the students read the text referring as needed to graphic organizer. After reading the selection, the students may return to the graphic organizer to clarify and elaborate concept. In this step, they may do it individually or in group. The last step is reviewing the students' graphic organizer. They may be different result on students' work. For that reason, the teacher should guide them so that they will have the same concept of graphic organizer.

\section{RESEARCH METHOD}

This research was in the form of quasi-experimental research which proposed to find out whether there was or not significant effect of the use of Graphic Organizer on students' reading comprehension. Besides, the group in this research was intact group. This research was designed by using PostTest Only Control Group Design.In this type of research design, it only considered post-test score in data analysis, while pre-test score was only used to find out the homogeneity and normality.

The data was collected after conducting a post-test. The data which had been collected was analyzed by using two forms of statistical analysis, descriptive analysis and inferential analysis. The descriptive statistical analysis calculated mean, median, mode, range and standard deviation. Meanwhile, the inferential statistical analysis was used to test the hypothesis. To test the hypothesis, parametric test of independent sample test or often called T-test was administrated. T-test was the test of the significance of the difference between two means. In taking the decision, if $t \geq t_{\text {table }}$ on the level of significance $5 \%$, with the value of $t_{\text {tablewas }}$ counted from the difference value of $t_{\text {table }}$ with $\mathrm{df}=\left(\mathrm{n}_{1}-1\right)$ and $\mathrm{df}=\left(\mathrm{n}_{2^{-}}\right.$ 1) divided by 2 then added by the total number of the smallest $t$, it meant that $\mathrm{H}_{a}$ was accepted and $\mathrm{H}_{0}$ was rejected and vice versa.

\section{FINDING AND DISCUSSION}

The data which were obtained in this research were analyzed by using two forms of statistical analysis, namely: descriptive statistics analysis and inferential statistics analysis. In descriptive statistical analysis, the data were analyzed in term of mean score, median, mode, range, and spread of desperation (standard deviation). The result of descriptive analysis could be seen in table 1.

Table 1: The Distribution of Data 


\begin{tabular}{llll}
\multirow{2}{*}{ No } & \multirow{2}{*}{ Statistics } & \multicolumn{2}{c}{ Group } \\
\cline { 3 - 4 } & & Experimental & Control \\
\hline 1 & Mean & 71.54 & 63.74 \\
2 & Median & 71 & 64.5 \\
3 & Mode & 71 & 66 \\
4 & SD & 9.43 & 10.2 \\
5 & Variance & 88.87 & 104.09 \\
6 & Range & 42 & 49 \\
7 & Max Score & 91 & 86 \\
8 & Min Score & 49 & 37
\end{tabular}

Table 1showed that the mean score of students who were taught using Graphic Organizer was 71.54. While the mean score of the students who were taught using Conventional technique was 63.74.From the data of reading comprehnsion test of the twelfth grade students of SMA N 1 Sukawati can be made data of distribution frequency of each group in the form of table and histogram.

Table 2 The Distribution Frequency of Experimental Group's Score

\begin{tabular}{cccc}
$\begin{array}{c}\text { Score } \\
\text { Interval }\end{array}$ & Frequency & Midpoint & $\%$ \\
\hline $37-44$ & 2 & 40.5 & 5.26 \\
$45-52$ & 1 & 48.5 & 2.63 \\
$53-60$ & 11 & 56.5 & 28.95 \\
$61-68$ & 11 & 64.5 & 28.95 \\
$69-76$ & 9 & 72.5 & 23.69 \\
$77-84$ & 3 & 80.5 & 7.89 \\
$85-92$ & 1 & 88.5 & 2.63 \\
$92-100$ & 0 & 96.5 & 0 \\
\hline 38 & & 100 &
\end{tabular}

Diagram 1The Histogram of Reading Comprehension of Experimental Group

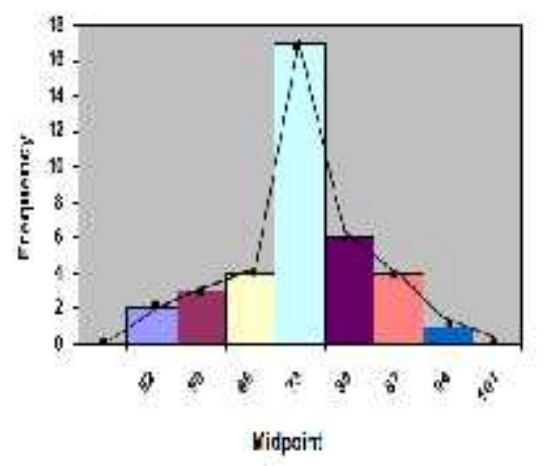

Diagram 1 presented that the seventh intervals was the highest frequencies comparing with the other intervals. In conclusion, the core interval 70-16 was the highest frequency.

Based on the table 1 about the distribution of students' reading comprehension score of those who were taught by using Graphic Organizer and Conventional technique, showed that the mean score of experimental group was 71.54, standard deviation was 9.43, minimum score was 47 and maximum score was 47 . Those mean score could be categorized into some categories.

Table 3 Category for mean score of students who were taught using Graphic Organizer

\begin{tabular}{cc} 
Score Interval & Category \\
\hline $80.03-91$ & Very High \\
$72.68-80.02$ & High \\
$65.33-72.67$ & Moderate \\
$57.98-65.32$ & Low \\
$69-57.97$ & Very Low
\end{tabular}

In table 3, it could be seen that the mean score of students who were taught by using Graphic Organizer was categorized as high.

Data of reading comprehension of the students who were taught by using Conventional technique had range score $86-37$; in which $\mathrm{n}=38$, minimum score $=$ 37 , maximum score $=86$, range $=49$, and standard deviation $=104.09$. The frequency distribution data can be seen in table 4.

Table 4.Distribution Frequency of Students' Score who were Taught Using Conventional technique

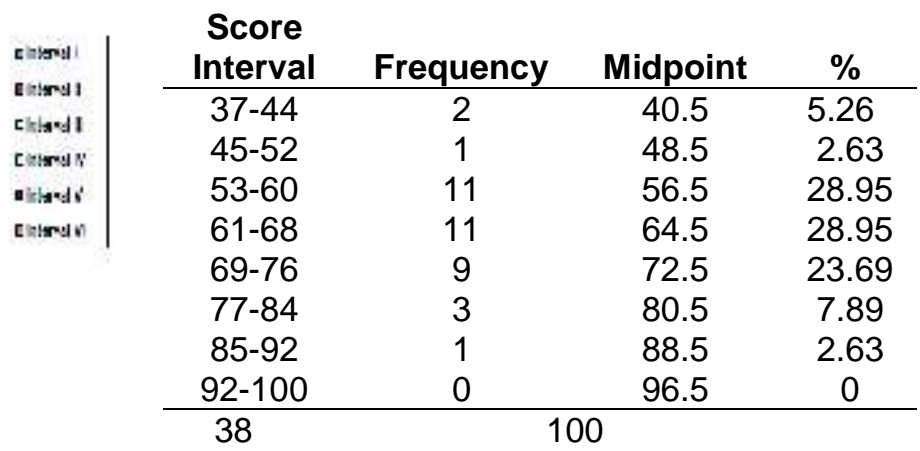


Diagram 2The Histogram of Students' Reading Comprehension Score of who were Taught Using Conventional technique

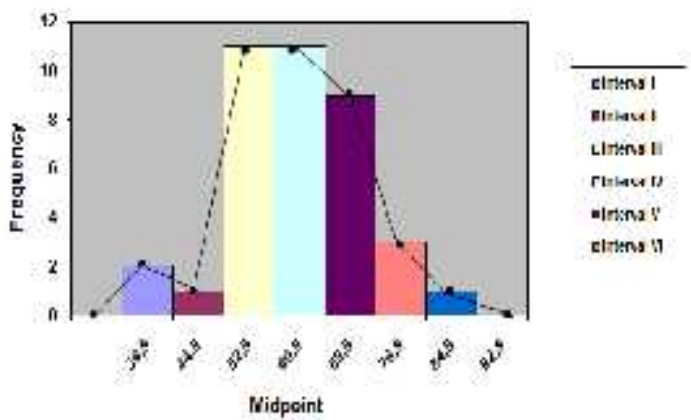

Diagram 2 presented that the third and fourth interval were the highest frequency comparing with other highest frequency.Based on the table 1 about the distribution of students' reading comprehension score of those who were taught by using Graphic Organizer and Conventional technique, showed that the mean score of control group was 63.74, standard deviation was 10.2, minimum score was 37 and maximum score was 86. Those mean score could be categorized into some categories.

Table 5 Category for mean score of students who were taught using Conventional technique

\begin{tabular}{ll}
\hline \multicolumn{1}{c}{ Score Interval } & \multicolumn{1}{c}{ Category } \\
\hline $73.77-86$ & Very High \\
$65.56-73.76$ & High \\
$57.41-65.58$ & Moderate \\
$48.23-57.40$ & Low \\
$61.50-48.22$ & Very Low
\end{tabular}

In table 5, it could be seen that the mean score of students who were taught by using Conventional technique was categorized as moderate.

There were several requirements needed to be fulfilled before analyzing the data. The requirements were whether or not the data were normally distributed and the variances were homogeneous. The analysis of each requirement will be discussed further in the following sections. Test of normality aims of finding out whether or not the data normally distributed. Analysis technique that is used to determine the normality is Chi-Square analysis $\left(X^{2}\right)$.

Table 6 The Result of Normality Test

\begin{tabular}{lcccc} 
Group & $\mathbf{n}$ & $\mathbf{X}^{\mathbf{2}}$ & $\mathbf{X}^{\mathbf{2}}$ table & Remark \\
\hline Experimental & 37 & 8.053 & 12.592 & $\begin{array}{c}\mathrm{H} \text { is } \\
\text { accepted }\end{array}$ \\
\hline Control & 38 & 4.039 & 12.592 & $\begin{array}{c}\mathrm{H} \text { is } \\
\text { accepted }\end{array}$
\end{tabular}

Based on the table 6, it could be described that $X^{2}$ of Experimental group was 8.053 and $X_{\text {table }}^{2}$ was 12.592. It meant that $X_{\text {table }}^{2}>X^{2}, \mathrm{H}_{0}$ was accepted and it can be inferred that the data was normal distributed. And the score of $X^{2}$ of Control Group was 4.518 and $X^{2}$ taolewas 12.592. It meant that $X_{\text {table }}^{2}>X^{2}, H_{0}$ was accepted and it can be inferred that the data was normal distributed too. In conclusion, both of those groups were normally distributed.

Homogeneity test of variance is used to know whether the groups of this research were homogenous or not. In testing homogeneity of variance of the data, F-test by Hawley. The result of homogeneity test could be seen in the table 7.

Table 7The Result of Homogeneity Test

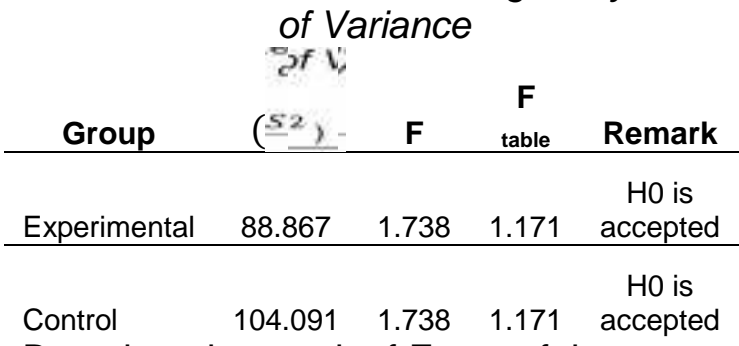

Based on the result of F-test of those two classes, the value of $F$ was 1.099 and $F_{\text {tablewas }} 1.734$. Because of 1.099> 1.734 , those two classes were homogeneous.

Hypothesis testing was used to test whether the research's hypothesis was accepted or not. In this research, independent sample test (T-test) was 
administered to test hypothesis since the data was normally distributed and the samples were homogeneous.

Table 4.8 The Result of T-test

\begin{tabular}{lcccccc} 
Group & $\boldsymbol{n}$ & $\bar{x}$ & $\mathbf{s}^{2}$ & $\mathbf{t}$ & trans & Remark \\
\hline Fxp & 37 & 71.54 & 83897 & 3.44 & 1.99 & $\begin{array}{c}\text { Hois } \\
\text { rejected }\end{array}$ \\
Otr & 39 & 63.54 & 104.091 & & &
\end{tabular}

Based on the data in table 4.8, it showed that both experimental group's and control group's analysis of T-test were $t \geq t_{\text {table }}$ in level of significance $5 \%$; null hypothesis (Ho) was rejected. It meant that there was significant effect between the students who were taught by using Graphic Organizer and the students who were taught by using Conventional technique.

Based on finding, the hypothesis null was rejected.The finding showed descriptively that the students who were taught by using Graphic Organizer performed better in reading comprehension test. It was proven by the result of reading comprehension posttest that was administrated for both groups. The mean score of the students who were taught by using Graphic Organizer was 71.54, while the mean score of the students who were taught by using Conventional technique was 63.74. Meanwhile, the finding showed inferentially the result of independent sample test (t-test) stated that the null hypothesis (H0) was rejected. This meant that there was significant effect there is significant effect in which the students' who were taught by using Graphic Organizer performed better in reading comprehension post-test.

The class which was taught by using Graphic Organizer in SMA N 1 Sukawati consisted of 37 students. The students of experimental group consisted of heterogeneous students. In giving the treatment through Graphic Organizer, the students worked in group to complete the graphic in every meeting. Nor \& Jin (2012, p. 33) state that Graphic Organizer provides an effective reading strategy that increase students' motivation, cooperative skill and reading skill. Graphic Organizer was conducted in whilst-activity specifically in exploration stage. The students were divided in several groups in which one group consisted of four to five students. The arrangements of groups' members were managed by the teacher purposely. Because of the class consisted of heterogeneous students, the formed groups would consist of high achiever students and low achiever students. Completing the graphic in groups will decrease students' anxiety if they feel unconfident in filling the graphic. Through working cooperatively the students can share each other and increase their motivation in learning as well as to drill their reading skill.

Another advantage of Graphic Organizer is also stated by Stull \& Mayer (2007, p. 808) in which by providing Graphic Organizer as a teaching strategy can induce students to engage in active learning, because they must think about how a linear text can be converted into a spatial structure such as a hierarchy or a flowchart. In group, the students were asked to discuss how to fill the Graphic Organizer based on their understanding of the text. Before filling the graphic, they should read the text first and then chose the key words that represented the content of the text. After filling the graphic, it was time for the students to tell the text based on graphic they had filled. This would examine their reading comprehension of a text and how effective Graphic Organizer helped them to understand the text. This process engaged the students in active learning because they had to understand the text, to think carefully about the appropriate key word, and to think how to convert a linear text consisting of a lot of words into spatial structure.

This result was supported by recent similar research conducted to investigate the effectiveness of Graphic Organizer upon students' reading comprehension. A research was conducted by Sam \& Rajan in 2013. The 
result of the post-test showed that the score of students who were taught by using Graphic Organizer had improved in all the five types of reading questions compared to the score of students who were taught using Conventional technique . Graphic Organizer also indirectly motivated the students to create their own Graphic Organizer of the passages they read and comprehended. From this research, it can be assumed that Graphic Organizer does not only help the students getting better reading comprehension, but also improving their creativity; in this case they create Graphic Organizer by themselves.

Based on the discussion of the finding described above, it can be inferred that there was a significant effect on the reading comprehension of the twelfth grade students who are taught by using Graphic Organizer strategy and who are taught by using conventional technique at SMA N 1 Sukawati in academic year $2015 / 2016$. It was proven that the students' who were taught by using Graphic Organizer performed better reading comprehension than the students who were taught by using Conventional technique.

\section{CONCLUSION}

Based on the finding and discussion of the finding in chapter IV, it can be inferred that the null hypothesis was rejected which stated that there is significant difference on the students' reading comprehension of the twelfth grade students' reading of who were taught by Graphic Organizer and Conventional technique at SMA N 1 Sukawati. It means that there was a significant effect of Graphic Organizer Strategy upon the twelfth grade students' reading comprehension at SMA $\mathrm{N} 1$ Sukawati in academic year 2015/2016. In conclusion, Graphic Organizer is an effective strategy for teaching reading for twelfth grade students.

\section{REFERENCES}

Alyousef, H.S. (2005). Teaching Reading Comprehension to ESL/EFL Learners. The Reading Matrix, 5 (2), pp. 143-154.

Badan Standar Nasional Pendidikan.(2006). Panduan Penyusunan Kurikulum Tingkat Satuan Pendidikan Jenjang Pendidikan Dasar dan Menengah. Jakarta

Best, J.W. \& Kahn, J.V. (2005). Research in Education Tenth Edition. Boston: Ablongman.

Deyuan, B. \& Yufen, G. (2006). Reading in Three Stages.CELEA Journal, 29 (4), pp. 124-126.

Erfani, S.M., Iranmehr, A., \& Davari, $H$. (2011).Deeping ESP Reading Comprehension through Visualization. Journal of Language Teaching and Research, 2 (1), pp. 270-273. doi: 10.4304/jttr.2.1.270-273

Jiang, X., \& Grabe, W. (2007). Graphic Organizer Reading in Instruction: Research Findings and Issues. Reading in a Foreign Language, 19 (1), pp. 34-55.

Johnson, A.P. (2008). Teaching Reading and Writing: $A$ Guide Book for Tutoring and Remediating Students. UK: British Library Cataloguing in Publication Data.

Kohler, P. (2009). Don't Tell Me; Show Me : Using Graphic Organizer Effectively. The Teaching Professor, 23 (6).

Koyan, I. W. (2012). Statistika Pendidikan Teknik Analisis Data Kuantitatif.Singaraja: Universitas Pendidikan Ganesha Press.

Learning Point Associates. (2004). A Closer Look at the Five Essential Components of Effective Reading Instruction: $A$ Review of 
Scientifically Based Reading Research for Teachers. US: Learning Point Associates.

Mahmood, M.H.K., Nikoo, F.R., \& Bonyandi, A.(2013). The Role of Schema or Background Knowledge Activation and Graphic Organizer on Increasing Iranian EFL Learnes' Reading Comprehension.European Online Journal of Natural and Social Science, 2 (2), pp. 229-241.

McKnight.K.S. (2010). The Teacher's BIG BOOK of Graphic Organizers. San Francisco: Jossey-Bass.

Mercuri, S.P. (2010). Using Graphic Organizer as a Tool for the Development of Scientific Language.Gist Education and Learning Research Journal, 4 (1), pp. 30-49.

Mikulecky, B.S. (2008). A Short Course in Teaching Reading: Practical Technique for Building Reading Power. Pearson Longman, Inc.

Nor, M.M., \& Jin, N.Y. (2012).Graphic Organizer and Paragraph Frame to Rectify Tunnel Vision. Is It Achievable?.Global Journal of Human Social Science, 12 (4), pp. 33-42.

Ozturk, O. (2012). The Effect of Graphic Organizer on Reading Comprehension Achievement of EFL Learners. Pamukkale University Journal of Education, 32 (2), pp. 37-45.

Sahiruddin.(2013). The Implementation of the 2013 Curriculum and the Issues of English Language Teaching and Learning in Indonesia.The Asian Conference on Language Learning 2013. Indonesia: Universitas Brawijaya
Salmi, M.A. (2011).Schemata (Background Knowledge) and Reading Comprehension for EFL Students.Research Journal Specific Education, (22), pp. 697708.

Sam D, P \& Rajan P. (2013).Using Graphic Organizers to Improve Reading Comprehension Skills for the Middle School ESL Students.English Language Teaching, 6 (2), pp. 155-170.

Snow, C. E. (2002). Reading for Understanding : Toward an $R \& D$ Program Comprehension. US: RAND

Stull, A.T \& Mayer, R.E. (2007). Learning by Doing Versus Learning by Viewing: Three Experimental Comparisons of Learner-Generated Versus Author-Provided Graphic Organizers. Journal of Educational Psychology, 99 (4), pp. 808-820. doi:10.1037/00220663.99.4.808.

Reyes, E.C. (2011). Connecting Knowledge for Text Construction through the Use of Graphic Organizers. Colombia Applied Linguistic Journal, 13 (1), pp. 719.

Wiriyani, A. (2011). The Effect of Semantic Mapping Reading Strategies on Students Reading Comprehension (An Experimental Study on the Eight Grade Students of SMP Negeri 1 Pekutatan).Unpublished Thesis. Universitas Pendidikan Ganesha.

Zaini, S.H., Mochtar, S.Z., \& Nawawi, M. (2010).The Effect of Graphic Organizer on Students' Learning at School.Malaysian Journal of Educational Technology, 10 (1), pp. 17-23. 